грулпе быно обиаружено 120 бацилоносителей. Послс спадения температуры кронь у подолытных больыы предсталляась почти иормальной. В одном только слуцас наблюхалисы симлтомы резлражсния мозговой коры, но они прошли сами собой, пе оставив инкакого сиеда.

B. Дембская.

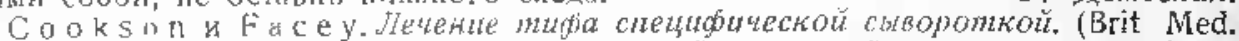
J. V. I $15 / \mathrm{V}$ 1937). Во еремя споралияеской тнфозий элилемин в 1936 г., вызвал:нон нелобюокачествеплым молоком, авторы ввели противотифозную сыворотку 73 из 500 тифозиы болылых, выбирая наболее тяжелые случаи. Больщинетво из пих получило сыворотку доволыно поздно, лри вполне развившейся инфекин, в срелней дозе $17 \mathrm{~cm}^{2}$. Автөры изучали действие сыворотки

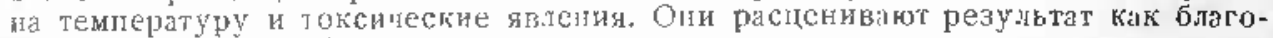
притный, еспи стойко повышения до этого температура сыижается втеqение 48 часов после ильскии, и паденис продолынется втечение последуюиих 7 дней. Влинние на токсэмия тонс долино быты заметиым н сказаться втече-

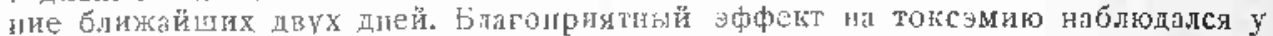
54 из 83 больных, У других 8 палиснтов улучшение настуило втечение от 2 ло 7 дней поспе введения сыворотки, Из леченнах сывороткой 7 больных умерли. У одного палюдаласы резко вьраженнал апафилактиеская реакция.

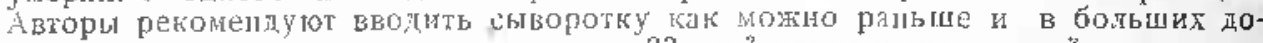
зах, у взрослых палиентон три раза по 33 см кондснтрированной сыворотки. 73. Lембоская.

Rogers, L. Контроль над пневнококковой пневмнией, осунествляемй̆ 6 umame Horo-Homka. (Am. J. Fubl. Health 1937, 2i, 2). Кák известно, крупозная пневмония с CIIA дает громадњый цроцент сиертности; поэтому в этой стране правилно проводимые тераневтисские и зпидемиологические мероприятя имет особенио большое зичение. А. подробно излагет схему борьбы с этим заболеванием, tт такте литературу, относящуюся к вопросу о серотерапии. Особенных успехов серотсраиия достигла после того, как стали прнменят концентрировањную сыворотку, Производство последней освоено полностью лиш

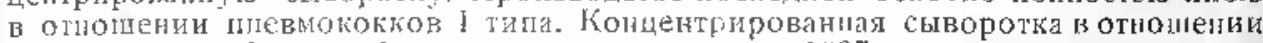
пневмококтов I] типа была изготовлена личь в 1937 г. и в настоящес врсмя

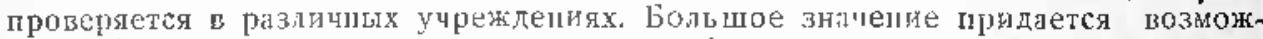
ности быстрого типирования пневмококка. А. отзывается весыма положнтельно o методе lī e ü $\phi$ e

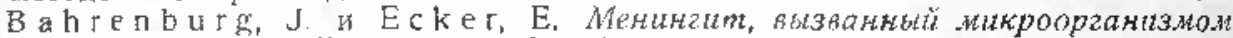
zpynntu Salmonella. (The Journ. of. lnt. Diseases, Vol. 60, 1937). Микроорга. низмы группы Salmonelia риспространены географияески повсюду и являютя важным фактором кишечных заболеваний. Однако известно сравнительно мало слунаев мелинцита, обусловленного представитслями этой груплы. Автор описывает одия случай менинй у семинедельного ребенка (с летальным исходом \& 24 часа), нз спинцомозговой жилкости которого бы. выделен микроб, относяцийся го свонм кулєтуральлым свойстван

Автор в своем союбщени разбираст олисаные до него 34 случая менингита с той же этиологией и считает, ито только у 19 больных было действительно услановено паниие Samonella, в остальных же слугаях отсутствует достагочио тщттельюе серологическос обстедованис.

I7. $P$.

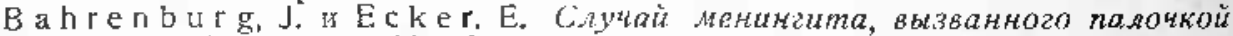
napamugo B. (J. Inf. Dis. 1937, 60 l). Аа. выделили из ликвора больного менин* гитом микроб, который окизаля принадлежаним к группе бацил.т паратифа В. Илснтификация штамма была произвелеға на основании детального изучения его биохинических, г такне серологических свойсть (р. агглютинации и адсорбини агглютининов). Мировая литература насчитывает 35 случаев менингта, вызванных паратифозной шалочкой; из них подробюое изучение штаммов было осупествлено пик в четырех, счнтая и настоящий случай.

\title{
б) Хupypzuя
}

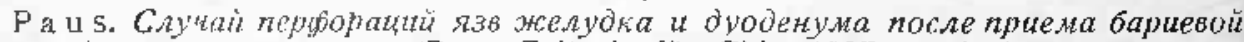

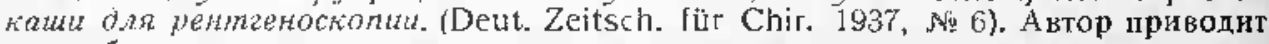
два наблюдения над редким осложнением при рентгеновком исследовании.

1) Мужчина приня 400 " о̆ариевой кали. Гентгеновское исследовпние обнаругило язву у основипия малой кривизвы желудка и затрудненное олорожнение из пего, На следуюшй день при дуоденалыюм зондированин б-ой испытал рсзкую боль. 